堆 積 学研 究, 44号, 15-18, 1997

J. Sed. Soc. Japan. No. 44, 15-18, 1997

\title{
A simple description of density current propagation in a flume
}

\author{
Yu'suke Kubo*
}

The motion of a density current in a rectangular channel can be described by coupled equations. The model includes the effect of slope, resistance exerted on a head of a density current and deposition of suspended sediments. Assuming that the volume of the head is $h^{2}$, the equations are reduced to simple forms with less parameters than previous models. Solutions show the downcurrent evolution of velocity of density current heads. The model is useful to quantify the behavior of natural large turbidity currents in a submarine channel.

key words: density current, turbidity current, velocity, gravity, resistence

\section{INTRODUCTION}

A density current is an intrusion of heavy fluid into lighter fluid, driven by relatively slight density difference. Turbidity currents are famous and important examples of density currents in which the excess density is due to the suspended sediment particles. Turbidity currents in lakes and the sea deposits enormous amount of sediments known as turbidites over large area. Turbidites are of great geological importance so that previous workers have attempted to understand the process of motion of and deposition from turbidity currents.

Many experiments have been carried out in laboratory to observe the characteristics of turbidity currents and their deposits (Middleton, 1966; Luthi,1980; etc.), because it is quite difficult to obtain direct observations of natural large turbidity currents. These experiments have established some empirical formulae and helped qualitative understanding of the nature of turbidity currents.

With the results of these experimental studies, many theoretical models describing the motion of density currents have been proposed. Most of them,

Recived : June 30, 1996, Accepted : October 17, 1996

* Graduate school of Science, Osaka University, 1-16, Machikaneyama, Toyonaka, Osaka 560, Japan however, are expressed in rather complex forms with many parameters although they are based on some assumptions and simplifications (Chu et al., 1979; Dade et al., 1994; Dade \& Huppert, 1995). While it is very difficult to describe mathematically the evolution of a natural turbidity current spreading over planar sea floor, in the case of a current restricted in a finite channel, a simpler description should be available.

In this paper, I propose a rather simple description of the evolution of a density current restricted in a laboratory flume. The main assumption is that the motion of a surge-type density current is represented by its head, rather than by the whole body of the current. As a result, the propagation speed of the head is given as a function of its travel distance.

\section{CONCEPT AND MODEL}

The simplest method to generate a density current is to release a finite amount of dense fluid from the lock into a horizontal or sloped channel filled with water. After removal of the lock gate, the denser fluid confined within a lock flows into the channel and forms an underflow or surge-type current (Luthi, 1980) at an initial velocity $v_{0}$. vo can be expressed in a simple form (e.g. Middleton and Southerd, 1984) by considering the change in potential energy and the resulting increase of kinetic energy 


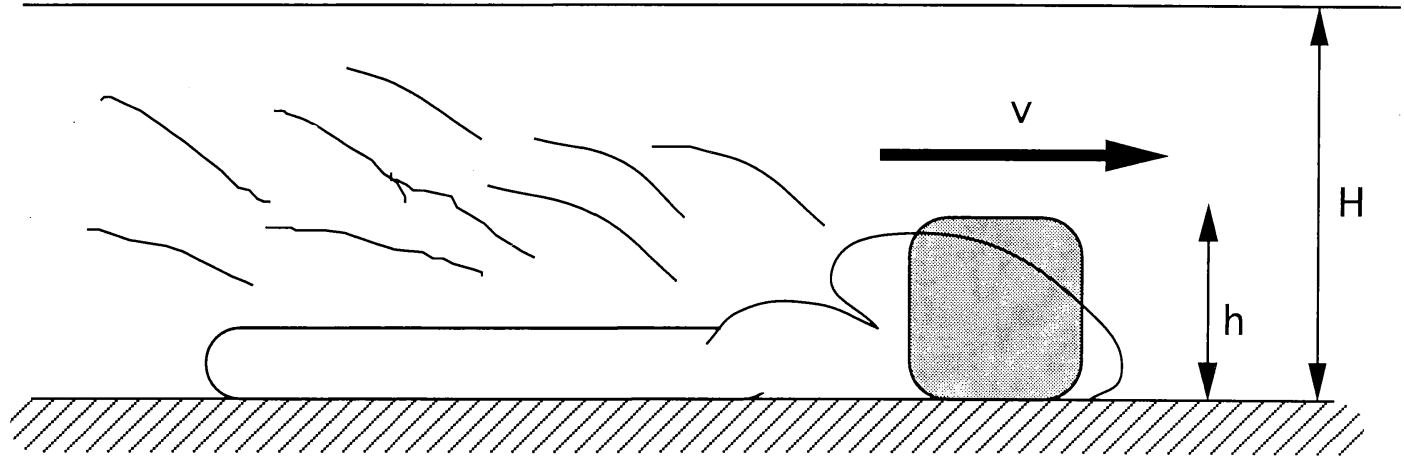

Fig. 1 A schematic illustration of a two-dimensional density current on a horizontal surface. Only the head of the flow contributes to the motion of the current. Volume of the head is set equal to $h^{2}$.

as:

$$
v_{0}=\frac{1}{2} \sqrt{\frac{\Delta \rho}{\rho+\Delta \rho} g H}
$$

where $\rho$ is the density of the ambient water, $\Delta \rho$ is the excess density of the flow, $g$ is the gravitational acceleration and $H$ is the depth of a channel. Although this result seems to be based on crude approximations, experimental studies show that it fits the observations rather closely (Middleton and Southard, 1984). On a steep slope, a surge-type current might be accelerated by the gravitational force, but no acceleration occurs on horizontal surface where the tangential component of gravity is zero without further supply of dense fluid from behind. On the other hand, friction at the boundary always works to decelerate the current.

In the present model, a surge-type current is modeled as a moving cloud of suspension, whose volume is constant and density is time-dependent (Fig. 1). This assumption is derived from the observation that the height of a density current changes only slightly with distance on a horizontal or very gentle slope (Luthi, 1980). As a result, the motion of a surge-type current is described by a momentum equation.

The equation of motion for the cloud is

$$
\frac{d}{d t}(m \cdot v)=\left(m-\rho h^{2}\right) \cdot g \cdot \sin \theta-R
$$

where $h$ is the thickness of the current, $m=(\rho+$ $\Delta \rho) h^{2}$ is the mass of the head, $v$ is the propagation speed of the head, $\theta$ is slope and $R$ is the total effect of friction. In equation (2), it is assumed that the volume of the two-dimensional head is equal to $h^{2}$, and that the mass lost from the head have no momentum.

The resistance $R$ in equation (2) is expressed as

$$
R=\left(\tau+\tau_{i}\right) h \cong C_{r} \cdot \rho \cdot h \cdot v^{2}
$$

where $\tau$ and $\tau_{i}$ are the shear stresses at the bed and the fluid interface respectively and $C_{r}$ is a coefficient of the total effect of friction.

The excess density of the flow decreases with the travel distance. Ashida et al (1981) showed by their experiments that the excess density of the turbidity current head decreased exponentially. Thus, $\Delta \rho$ is assumed as

$$
\Delta \rho=\Delta \rho_{0} \exp \left(-C_{d} \cdot x / h\right)
$$

where $\Delta \rho_{0}$ is the initial excess density of the flow, $C_{d}$ is a coefficient describing the total effect of dilution and $x$ is the travel distance of the head from the release point of dense fluid. The excess density decreases with distance mainly by depositing suspended particles. $C_{d}$ in equation (4) should be evaluated from experimental data.

Substituting equation (3) and (4) into (2) yields

$$
\begin{aligned}
& v \frac{d}{d x}\left\{h\left(\rho+\Delta \rho_{0} \exp \left(-C_{d} \cdot x / h\right)\right) \cdot v\right\}= \\
& \Delta \rho_{0} \exp \left(-C_{d} \cdot x / h\right) \cdot g \cdot h \cdot \sin \theta-
\end{aligned}
$$




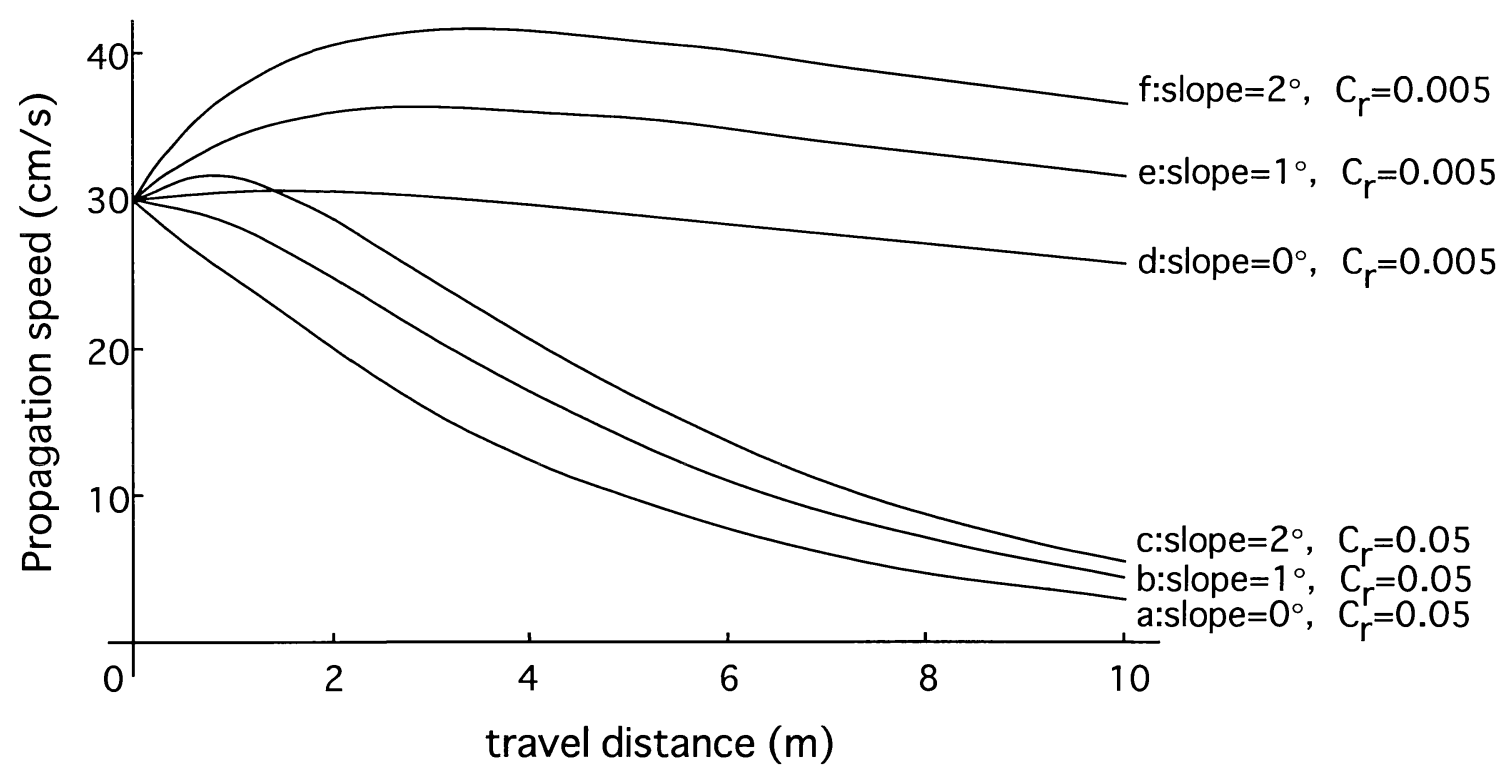

Fig. 2 Examples of numerical solutions for equation (5) showing the downcurrent evolution of velocity of density currents. Initial values are set as $H=40 \mathrm{~cm}, h=20 \mathrm{~cm}$ and $\Delta \rho_{0}=0.1 \mathrm{~g} / \mathrm{cm}^{3}$. $C_{d}$ is given so that the excess density decreases to half of its initial value in $1 \mathrm{~m} . C_{r}$ and slope are varied as indicated.

$$
C_{r} \cdot \rho \cdot v^{2} \quad(5)
$$

Equation (5) cannot be solved analytically but gives numerical solutions with appropriate initial values.

\section{RESULTS AND DISCUSSION}

Examples of the numerical solutions of equation (5) are plotted in Fig.2, which shows the downcurrent change of the propagation speed of the head for different conditions. The initial values are set as $H$ $=40 \mathrm{~cm}, h=20 \mathrm{~cm}$ and $\Delta \rho_{0}=0.1 \mathrm{~g} / \mathrm{cm}^{3}$, all of which are common in laboratory fluid systems (e. g. Luthi, 1980). These values determine the initial velocity of the head by equation (1). $C_{d}$ is given here so that the excess density decreases to half of its initial value in $1 \mathrm{~m}$. Generally, $H, h, \theta, \Delta \rho_{0}$ and $C_{d}$ can be controlled or easily measured in a laboratory system. $C_{r}$ is set equal to 0.05 or 0.005 , for $\theta$ ranging from $0^{\circ}$ (horizontal) to $2^{\circ}$.

The effect of varying $\theta$ and $C_{r}$ on the velocity predictions is shown in Fig. 2. As the slope becomes steeper or as the resistance coefficient becomes smaller, the head advances faster. The head is accelerated from its initial velocity in Fig. $2 \mathrm{c}, \mathrm{d}$, e and $\mathrm{f}$. It is noted, however, that the model is not be applicable for the prediction of the behavior of the head on a steeper slope because $h$ (height of the head) changes with distance by water entrainment.

The values of $C_{r}(0.005$ and 0.05$)$ used in Fig. 2 are given rather arbitrarily. They are larger than 0.0035-0.004 which is generally used as a coefficient of the bottom shear stress (Komar, 1985). This is because that the total resistance exerted on a current head include not only friction at the bed $(\tau$ in equation (3)) but also that by surrounding water $\left(\tau_{i}\right)$. With the value 0.005 as $C_{r}$, the propagation speed of the head is decelerated only slightly within $10 \mathrm{~m}$ of the downcurrent distance even on horizontal surface (Fig. 2d). Middleton (1966) showed from his experiments, refering to a Chézy-type equation for steady and uniform flow, that the total resistance coefficient $f\left(=8 C_{r}\right)$ was ranging from 0.03 to 0.06 $\left(C_{r}=0.004-0.008\right)$ for small slope $\left(<1^{\circ}\right)$. When the current decelerates more rapidly, however, the larger value of $C_{r}$ such as 0.05 is needed. In that case, friction exerted by surrounding water $\left(\tau_{i}\right)$ is dominant over total resistance. This model will, by comparison with experiments, lead to estimations of 
total resistance exerted on the turbidity current head.

This model includes only two unknown parameters, $C_{r}$ and $C_{d}$, to express the motion of a density current in a finite channel. Although in natural settings it should include more parameters in complicated forms, this simplified model is useful to predict the overall behavior of turbidity currents. After verifying the appropriateness of the model, it should be extended to involve the ignored effects such as geometry of a channel and characteristics of fluid.

\section{ACKNOWLEDGEMENTS}

I wish to thank M. S. N. Endo, Professor F. Masuda and Dr. M. Yokokawa for helpful comments on earlier versions of the text.

\section{REFERENCES}

Asida, K., Egashira, S., and Nakagawa, H., 1981: Behaviour of turbid water mass released into two dimensional reservoir. Bull. Disast. Prev. Res. Inst., Kyoto Univ., Vol. 24, B-2, 265-282.

Chu, F.H., Pilkey, W.D. and Pilkey, O.H., 1979: An analytical study of turbidity current steady flow. Mar. Geol., 33, 205-220.

Dade, W.B., Lister, J. R. and Huppert, H. E., 1994: Fine-sediment deposition from gravity surges on uniform slope. Jour. Sediment. Res., A64, 423-432.

Dade, W. B. and Huppert, H. E., 1995: A box model for non-entraining, suspension-driven gravity surges on horizontal surfaces. Sedimentology, 42, 453-471.

Komar, P. D., 1985: The hydraulic interpretation of turbidites from their grain sizes and sedimentary structures. Sedimentology, 32, 395-407.

Luthi, S., 1980: Some new aspects of twodimensional turbidity currents. Sedimentology, 28, 97-105.

Middleton, G. V., 1966: Experiments on density and turbidity currents, II. Uniform flow of density currents. Can. Jour. Earth Sci., 3, 627-637.

Middleton, G. V. and Southard, J. B., 1984: Mechanics of sediment movement, 2nd Ed: S. E. P. M. short course No. 3, 342p.

\section{水路内での密度流の運動の簡単な記述}

\section{久保 雄介}

密度流の水路内での運動は連立方程式で記述することができる，この方程式には斜面，密度 流の頭部に働く抵抗と，浮遊粒子の堆積の効果が含まれている.頭部の体積は $\mathrm{h}^{2}$ であるとする と, 方程式はこれまでに知られているモデルょり簡単な形で表すことができる，その解は密度 流頭部の下流方向への速度変化を表す．このモデルは, 海底チャネルを流れる自然界の大規模 な乱泥流の運動を定量化するのに有用である。 